\title{
The Efforts to Increase the Income of Sulfur Miners through Economic Transformation in Mount Ijen Banyuwangi, Indonesia
}

\author{
Aliya Fatimah' ${ }^{1}$, Wahdjoedi, ${ }^{2}$, Danardana Murwani, ${ }^{3}$,Mit Witjaksono, ${ }^{4}$ \\ ${ }^{1}$ (Post Graduate Program, Universitas Negeri Malang, Indonesia \&Universitas Bakti Indonesia \\ Banyuwangi,Indonesia) \\ ${ }_{2}^{2}$ Universitas Negeri MalangMalang, Indonesia ) \\ 3 (Universitas Negeri Malang, Indonesia) \\ ${ }^{4}$ (Universitas NegeriMalang, Indonesia)
}

\begin{abstract}
This article will explain more about the lifeand economic condition of the sulfur miners whoare located on Mount Ijen, Banyuwangi Regency, which is very famous with panorama of natural beauty such as blue flame of fire. Behind the natural beauty, there are some sulfur miners on Mount Ijen whoare still experiencing difficulties in meeting their needs.It is because the income for transporting sulfur income is still very low, so it can only be used to meet the daily needs alone. The purpose of this study is to see what efforts can be done by sulfur miners to help increase their incomes.This research was conducted in Licin village, Licin subdistrict, Banyuwangi Regency, by creating a second job for sulfur miners which is in accordance with the existing potential in mining community environment, with research time about 12 months. This study used a qualitative approach by using technique of observation, interview and documentation. The result of this study will show (1) concrete efforts which are done to increase the income of sulfur miners to involve the local community as well as utilize the potential of the existing environment, (2) the side jobs that is done have a system that is sustainable or long-term so as to contribute to the enhancement of the incomeof sulfur miners in Banyuwangi.
\end{abstract}

Keywords: Increase of Income, Economic Transformation, Sulfur Miners. Economic Transformation, Sulfur Miners, Family Economy

\section{INTRODUCTION}

Banyuwangi is the most eastern part of East Java Province, with a height of between 25-100 meters above sea level. It is a regency which has a long coastline of about $175.8 \mathrm{~km}$ that stretches along the southern boundary of EastBanyuwangi, and has 10 islands. Banyuwangi Regency has slopes of more than $40 \%$ covering approximately $29.25 \%$ of the total area that has a high point of more than 500 meters above sea level.The study was preceded by a thought about the phenomenon that occurs in the area of Mount Ijen, which is famous with the tourist area that is in demand of both local and foreign visitors. Besides the beautiful crater, there are some people who worked as sulfurminers and carriers. Even though theoccupations as miners and sulfur carriers, which have been used as a tourist attraction because it is assumed as rare jobs and hasexotic value,they are not easy jobs. The miners who generally come from Licinsubdistrict and Licin subdistrict. To be able to do mining, the miners have to leave home at about 2 to 5 am to reach the parking lots, then they have to climb about four kilometers to reach the crater rim to take sulfur [1]Sulfur mining in Banyuwangi Regency is one of the places where people of Banyuwangi can meet the needs of everyday life, but if we observe it closer and directly, sulfurminers in Banyuwangi are very different with the term of miners which are often described by many people, that miners have high incomes and live in affluent.

\subsection{Research Focus}

In this study, the focus of the research is directed to answer some of the basic issues regarding the improvement of the economy that is democratic in the slopes of Mount Ijen, especially the sulfur miners: who, when, where, why, how and to what extent the prospect of a job as sulfur miners and also economic improvement which is done by sulfur miners in Licin subdistricts, Banyuwangi. The miners will be invited together to improve the existing income through the utilization of potentials that exist around them.Briefly, the focuses in this research are:

a. How is the effort to increase the income of sulfur miners in Ijen Mount Banyuwangi?

b. How is the process and also the success in economic development of sulfur miners in Ijen Mount Banyuwangi? 


\subsection{Research Goals}

The purpose of this study is to solve the problems that have been formulated before. In general, the research aims to identify, analyze, describe and understand the meaning of economic empowerment and growth in the area of Banyuwangi, particularly for sulfur miners. So the meaning of economic improvement for the sulfurminers will be found, which is used as inspiration and real-life examples in economic development by other miners .

\subsection{The Functions of this Research}

The axiologysubstance in research is principally discussing the value of the research results. Benefits of the research is for the benefit of science and the value of practicalhumanity.

The benefits of this research are expected to be useful for the followingparties:

a. For the sulfur miners who are observed, the results of this study will be a valuable motivation to improve income and management of incomewhich have been obtained by the sulfur miners, as well as the development of other businesses besides being a sulfur miners.

b. For policy makers, especially for government of Banyuwangi, the result of this research can be served as a model of economic enhancement of the sulfur miners.

\section{LITERATURE REVIEW}

\subsection{The economic empowerment of families}

The term of family can be understood as the smallest social unit in society, or an organization of bio psycho - socio- spiritual, where family members are involved in a special bond to live together in matrimony and the bond which is shackled to each other in harmony between one another. While in Arabic, it is al Usrah, which is derived from word al - Asru, which etymologically has the meaning of a bond, but later it is spread to everything well tied with string or another.

The role of family in arranging children's life is a big responsibility for parents, then there is a need for parents to be aware in preparing themselves with knowledge and experience in order to create aconducive learning environment family .

Family environment as a medium of education has functions in family education, namely: Government Regulation of the Republic of Indonesia number 21 of 1994 Article 4, paragraph 2, which states the function of family in the social system of life, which are: a) educative function, b) economic function, c) protection function, d) recreation function, e) a religious function, f) environmental management function, g) affection function, h) the function of love, i) reproductive function, j) the function of social and culture. [2]

In particular, the empowerment of the family will be aimed at vulnerableand disadvantaged groups,empowerment program is aimed at:

a) Structurally weak group (primary structural disadvantage) including class ( the poors, the unemployeds, lowpaid workers).

b) Weak group, specifically the elderly, children and youth, the disabled and isolated communities, and

c) Personally weak group is those who are experiencing personal problems and family.

The fulfillment of low income and the job change in the life of the household or family isforced to be able to do thinking creativity towards the growth of jobs in productive economy in household scale, which is by encouraging the entrepreneurship. Entrepreneurial spirit that grow out of the family environment, and develop into an important factor of the growth of the entrepreneurship community. Because people's lives is widely influenced by patterns of domestic life in the community environment

c. Society Empowerment

The weak position of communities in certain regions especially in the mountain community, especially sulfur miners in Mount Ijen, there have appeared some people's empowerment. This program is one form of responsibility of the article 33 of UUD 1945.

While the economy in the traditional rural communities basically is done hereditary and tends to be static because of the lack of initiative to make changes of the economic behavior, in aspects of consumption, production and distribution and improvement of business management. Economic literacy will happen if there is an initiative to change jobs in the sulfur miners, so that productivity will be essential in the global world, an effort that has competitiveness.

d. Economic Transformation

Economic transformation is a process of change that occurs in the structure of the economy, which is marked by a shift from one economic sector to another sector of the economy that can influence the change in the Gross Regional Domestic Product of a country or a region. [3]

In terms of economic development is not only an economic process, but rather a manifestation of social and culturechange, development is basically always involves the changes in perception and attitude towards life as a 
whole, not as separated parts; therefore, every process of economic development always concerns on noneconomic factors in it [4]

Economic transformation basically have different speeds, it is because the status of ownership and natural resources which is available, the quality of human resources and culturization process. The change of mindset will be expected to promote changes in the economy, especially for sulfur miners would also be affected by the process of social transformation.

\subsection{Approach and Types of Research}

\section{METHODS}

Research on improving the economic welfare of sulfur miners in the Licin village, Licin Subdistrict, Banyuwangi, is a qualitative research method with interpretative paradigm, where this approach would later interpret phenomena that exist on the slopes of Mount Ijen, especially inthe life of sulfur miners community. While the interpretive paradigm analyzes social activities through direct observation which are detailed on the individual in situation and natural conditions they are experiencing with the aim to reach an understanding and interpretation of how people create and maintain their social world. [5]

Qualitative research, which is also called interpretive research or field research, is a methodology borrowed from disciplines such as sociology and anthropology and adapted to the education world. Qualitative research uses inductive reasoning methods which focuses on social phenomena and on voting feelings and perceptions of the participants under study. [6]

\subsubsection{Data Sources}

This study is conducted in the slopes of Mount Ijen, especially on sulfur miners (as the focus of research) especially in Licin Village,which is served as research samples. Licin village is chosen as one research site in order to be able to answer the research problem, which is about the economy of sulfur miners in Banyuwangi Regency. This study covers all of sulfur miners and surrounding communities ofsulfur miners. The research samples are the sulfur miners, community leaders and families of miners. The sampling is based on a purposive sampling techniques, namely by taking subjects, which is not based on strata, random, locations, but it is based on specific objectives.

In addition, to get the information from different types of sources, especially the master of the severity of economic problems of sulfur miners. The informants who are selected in this study is informants who really understand about the condition of the bekerang miners, who are: the village head, the RT, employees of PT Candi Ngrimbi that since 1968 has been a single firm that manages sulfur in Banyuwangi, also a member of the family including the wife and child sulfur miners.

\subsubsection{Data Collection Technique}

Data collection techniques used in this research is by making observations, interviews, and documentation. Data collection can be itemized as follows: (1) observation, which is the way used by researchers to see and know the sulfur miners' activity in the crater of Mount Ijen. (2) Interview, the way used by researchers to uncover how the research subjects give meaning to his work as sulfur miners. (3) Documentation, which is one way to put researchers to gather and put the terminology and the sources of the theory in this research is the theory concerning on the sulfur miners empowerment.

\subsubsection{Data Analysis Technique}

Data which are collected through observation, interview, and documentation in this research are in the form of qualitative data. The technique which is used to analyze the research data is interpretative descriptive analysis technique with the steps as follows: (1) Select a relevant document / data and give code. (3) create an objective record or note, in this case also classify and edit (reduce) the answer (2) create a reflective note, which write down what the researcheris thinkingas an interpretation of the relation with the objective records. (4) conclude the data by creating a format based on the data analysis techniques which is wantedby researchers. (5) Perform triangulation, which checks the accuracy of data by concluding double data which are obtained in three ways: (1) extend the time of observation in the field with the aim to match the data that has been written with the field data, (2) match the data that has been written by asking to the informant again, and (3) match the data that has been written with the literature sources. [6]

\subsection{The Condition of Sulfur Miners in Banyuwangi}

\section{DISCUSSION}

Sulfur mining in Banyuwangi has been initiated since 1968, The discovery of abundant sources of sulfur because of the project ofMr. Ceh to find new sources of sulfur, then 26 people were sent from Tretes to review Mount Ijen and the presence of sulfur. Meanwhile,from those 26 people, only six people still survive, 20 
people resigned because of the terrain which is crossed is quite difficult and needs to cut down the forest to be used as the path to a source of sulfur, six people who still survive are Trimorejo, Daim, Dikno, Sunoto, Samin and Tahar. [8]

The condition of mining this time do not experience much changes, only for the current weighing place that is closer to the location of sulfur, and the transport facilitywhich is provided by the company for the transport of sulfur. However, many sulfur miners who drive motor vehicles to the weighing place (Paltuding) some miners also have a motor vehicle they had thought that " why bother to work if you can not enjoy it". Then to be able to reach the crater rim of the carrier, we still have to walk down a cliff as far as $4 \mathrm{~km}$. Up to September 2014, when the price of sulfur has reached 900 IDR per kilogram to the first transport, if any miners were carrying twice then the second transport will be charged 1.000 IDR per kilogram.

\subsubsection{Profil of Sulfur Miners in Banyuwangi}

The age of miners up to 2013 ranged from 20-64 years old, with a payload capability of about 40 to $100 \mathrm{~kg}$ per person. However from 2013 until now many miners who are still young decided to stop being miners, miners who are young choose another job. This isbecause the inability of young miners with jobs that require a very strong power. For once transport, the sulfurminers can bring home the money amounting to 36,000 IDR to 99,000 IDR.

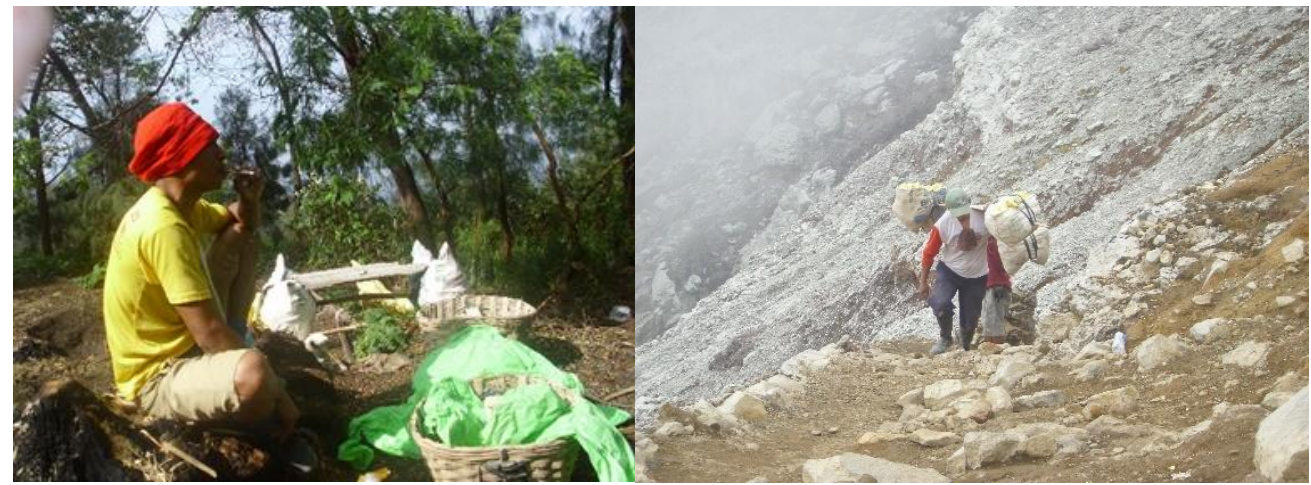

Image1. Difference of 20 year-old miner and 64 year-old miner

In general, the carriers only work for 20 days a month because the carrierscannot do mining activities everyday. According to a sulfur carrier named Kauli,by transporting or carrying 20 days a month, the daily needs of his family will not be fulfilled, here is an explanation of KL in the interview :

... Anyway I domining activities as long as I am still strongand I can do it. The mining activity is only off Friday. If I do not work everyday, I cannot fulfill the meet of my family. Especially if there are many holidays,my family cannot have food to eat. Besides that, I have to pay installment of motorcycle for my son. ( ww. KL. Wednesday, November 26, 2014)

The lack of income lead the miners and transporters to think hard again about how their children can get better jobs than this (sulfur miners).

With the price of sulfur which is 900 IDR perkilogram, it apparently does not help much the miners to fulfill their daily needs, especially for those who have children in large numbers.It becomes a problem for the miners who are too old and no longer strong enough to carry loads that are too heavy. Finally, the miners who are classified as seniors only transport sulfur as much as they can without any targets.

This problem must be one of the obstacles for miners in meeting their needs, but needs to be met at this time is very high, besides the health effects that will be experienced by the miners that damage their lungs as a result ofinhaling sulfur gasesfrequently, which is released by the crater where the gas contains a toxin that can be stifling breathing. Cough disease is still much experienced by sulfur miners to up to now, in addition to other diseases such as difficulty to walk or back pain, it can be felt by miners because of a the heavy loads that had been imposed on their body.

The condition of the sulfur miners is difficult if it is viewed from the economic aspect, but the miners have a social life that is very well preserved.The togetherness can be seen from a sense of awareness among the miners. There isa fear of the miners if some of them do not come to transport sulfur, the together they are feeling at this time both at the work or home environment can be served as an excellent social capital which is be able to maintain their lives. [9]

For the houses of sulfur miners, the physical condition of the house occupied until today, there are still many sulfur miners who still rent houses for them to live in, and houses that is still semi-permanent and houses that are still not permanent yet. Homes of the sulfur miners have a relatively small size, whoich walls are made 
of " gedhek" (bamboo) and roof tiles then still a dirt floor. If it is viewed from the house condition stte and the calculation of income, it can be said that the economic condition of sulfur miners is still below the average.

\subsection{The condition of sulfur miners from economic aspect}

People who are located around the Ijen crater mostly work as farmers and workers, who still have low level of education. They work by utilizing the natural resources around one sulfurarea which is located in Mount Ijen.Before the sulfur miners became miners, there are some jobs that they do, including working as farm laborers and plantation workers.Farm laborers in Banyuwangi are the same as farm laborers in other areas, who only work on seasonal time. They only work on the time will start working on the fields and will work again when the harvest arrives. Then there are also people who work as coffee and clove pickers inplantations.Coffee and clove pickers also workin the seasonal time, which at harvest time only. Before they work as sulfur miners, they work as tire repairman and construction worker, who on average can make money between 600,000 IDR to 900,000 IDR a month. Their income is not sufficient to fulfill their daily needs. In life, humans require both sepiritual and material needs, in relation to the human needs,so they want to meet their needs until the satisfaction level is reached. Because the miners do not have land and special skills so they choose to work as sulfur miner.

Theaverage ofthe income of sulfur miners itself if it is viewed from the heavy load of sulfur is between 40-100 kilograms of sulfur prices are now starting tanggai September 1, 2014 reached 900 IDR for the first batch and 1,000 IDR for the second batch . Then the sulfur miners daily average can both earn between 36,000 IDR to 99,000 IDR in a month that miners can work for 20 days. Therefore, the monthly income of sulfur miners can range between 720,000 IDR to 1.98 million IDR. The number of earnings will be used to meet their daily needs within a month .

The increase of the price of sulfuris caused by the anxiety of many companies which begin to lose the members of sulfur carrier. Sulfur miners who are still young today are turning to another job because before September 2014, precisely on June 23 2013, the price of sulfur was only780 IDR per kilogram. The increase of the price of sulfur is very slow, the average of annual sulfur prices can only go up 100 IDR to 120 IDR per kilogram only, and even then it should started with a demo of the sulfur carrier .

Miners who are capable of carrying twice of the loadthey usually carry are miners who have debt. Nowadays, many sulfur miners who purchase motor vehicles with a credit system. Therefore, if the sulfur miners only carry sulfur once,they cannot fulfill their needs as well as their dependents. Actually, transporting sulfur twice is not in accordance with their physical ability. It can be seen from quite the terrain which is quite difficult.

However, starting from 2014,there were a lot of sulfur miners who switched professions, which means that therewere many sulfur miners who have left their job as sulfur miners because they thought that it is better todo other jobs though the income is not as much as sulfur miners but they also do not bear the safety riskwhich is quite high. It is one of the reasons of the low price of the company in providing sulfur to the carrier .

Some informants who have much talked about their family life when they become sulfur miners:

Since I became a sulfur miner in the early 90 's until 2013, my family life still had not changed. My income is just enough to buy food. When I was 25 to 40 years old, I can liftas much as 100 kilogram of sulfur, and I can get a lot of money. However, the moneyis also just enough to meet the daily needs alone. You know the condition of my house, right? It is still made of bamboo. (WW, KL. 04:00 pm, 23 September 2014).

The next explanation in January 2015, when investigators visited his home in Tlemung village, Kalipuro subdistrict, different conditions can be seen there. The renovated houselead the researcher to ask a lot of questions.

The following is the report from an informant named Kauli, who became miners starting in 1990 : Iyo mbak...isun saiki belajar dadi gaet, nambang mulai tahun 90 ga onok perubahan blas..akhire aku milu nggaet koncoku..hasile lumayan mbak, setahun isun biso dandan-dandan omah, lumayan masio hing bendino tapi hasile lumayan. Opo maneh lek tamune teko prancis mbak..wonge ga medit, akhire yo ngene isun iso gawe omah anyar.(WW. KL 10.00 wib, 15 Januari 2015).

(Yeah, now I've learned to be a guide, so the mining started from 90 'shad not changed at all. I finally joined my friends as a guide, the result is quite much.In one year, I can renovate my home, although I do notwork every day but the result is not bad. Especially if the guest comes from French, they are not stingy at all, until finally I could make new home..translation ).

It is such a fortune for miners who could have dual profession as a guide (guide) as miners called Kauli. But it is not easy to make changes for miners who are old or who are reluctant to learn to understand how to make changes.

As the economic image of sulfur miners today, when it is seen from the daily income and also expenses. 


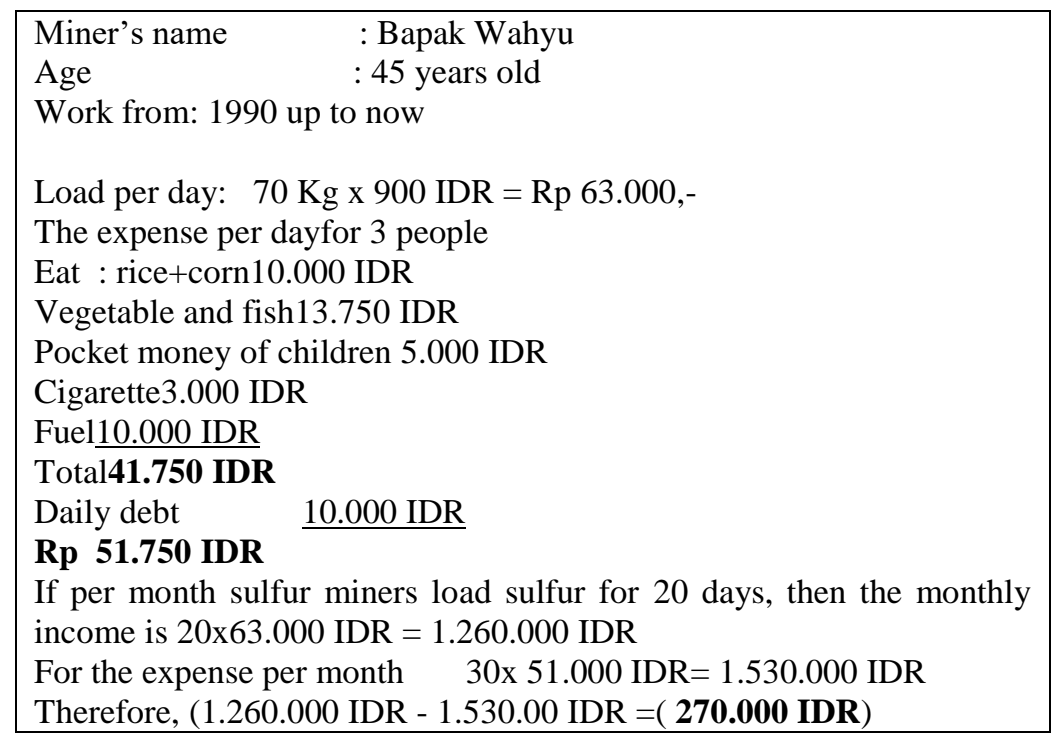

The sulfur miners named Mr. Sukidin has been doing mining activityfrom 1970, and the capability of lifting or carrying sulfur until now is only 40 kilograms. Up to now, he remains to be sulfur miners. The persistence of Sukidin to be none other than sulfur miners is also because he does not have expertise in other areas.

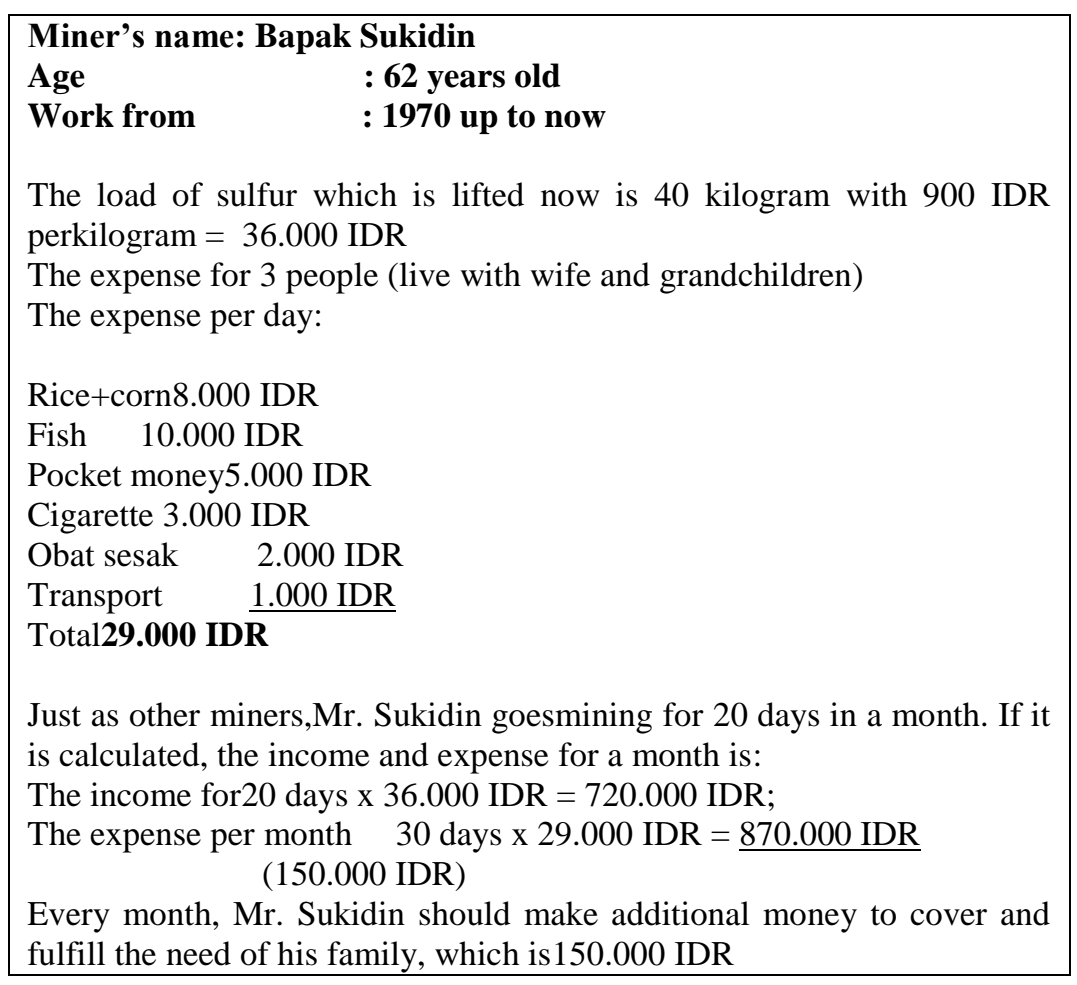

Example of calculation of income and expense household of sulfur miners inLicinVillage above cannot absolutely be used as a benchmark to measure the family welfare and of sulfur miners' family inLicinVillage. This is because the miners experience fluctuating income annually. If it is viewed from the price of sulfur, it can be said that the income increase, but when it is viewed from the economic condition, the welfare of the miners still have not increased.

\subsection{Economic Transformation Facility of Sulfur Miners}

Current economic condition of sulfur miners in Banyuwangi is that they already started thinking about how the continuation of his life, also for the young miners who also started to think about the education of their children. They also do not want their children to suffer the same fate by always carrying a load of sulfur on their shoulders. Additional work has been done by some sulfur miners today, including:

\subsubsection{Tour Guide}


Sulfur miners, in particular who are between 20 years old to 45 years old, have begun to think ahead and be able to read the opportunities that exist in the mining environment. One of the potentials that is in demand by visitors of Mount Ijen is the presence of blue flames or ften referred to as blue fire, especially visitors from abroad. They are very keen to see the blue fire directly, and some even come up to ten times or more. The potential that exists in the environment of Ijen crater is really utilized by sulfur miners who still have a passion to learn. The opportunity to become a tour guide is very potential, it is because the miners themselves deeply understand the terrain which is very difficult and endanger visitors if the do not know mining sites. The income to be a tour guidein one-way tour reaches 400,000 IDR to 600,000 IDR. If within one month they can accompany guest three times, the additional income of sulfur miners increase to 1.200 .000 IDR to $1,800,000$ IDR.The job is very helpful for the miners to increase their income.

Obstacles faced by sulfur miners who have second job as tour guide is the limitation of language ability and very low interest to learn. However, this the sulfur miner is smart enough in negotiating how to learn language rapidly, which is by writing the words in accordance with what is said, so this way is very easy to put into practice. The tour guide in the area of Mount Ijen only needsto speak a sentence without the need to learn the correct way of writing.

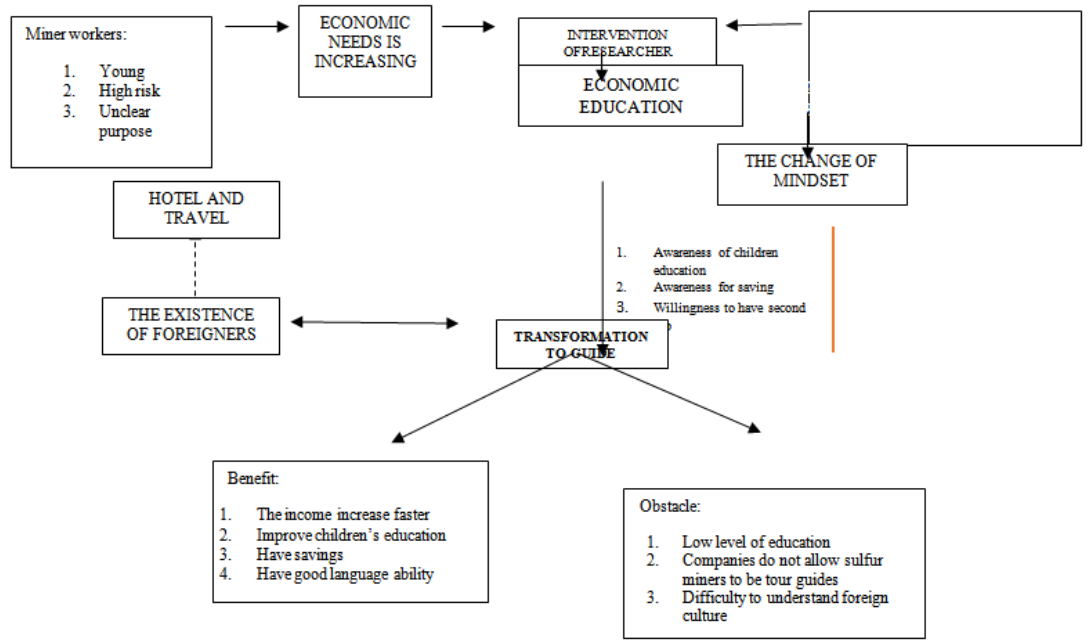

Figure1.Transformation process of sulfur miners to tour guid

\subsubsection{Home StayService}

The very high social sense of sulfur miners enable them to enjoy the secondary product together. Sulfur miners who are not capable of learning foreign languages prefer to set up lodging in her house for the foreign tourists who want to enjoy a natural life in the countryside. Cooperation between sulfur miners who become guide and who open the business of home stay is a series of synergy because they need each other and help each other. Guides who have guests, especially travelers from foreign countries, immediately direct their guests to stay in inn or home stay managed by their friends of other miners who open a home stay .

The cost forstayingin miners' house is very cheap, both for local and foreign tourists. Sulfur miners who open home stay just fix the rate of between 100,000 IDRto 150,000 IDR, depending on how many times they provide food. They guests are treated like the owners' own family,like watching TV together or eating together with family members. This is the main attraction for foreign tourists. Togetherness and social sense which is quite high .

Constraints faced by sulfur miners in opening a home stay business is the limitedfacilitywhich is provided, such as the bathroom facilities. This makes the sulfur miners encouraged to borrow money to build a decent bathroom. 


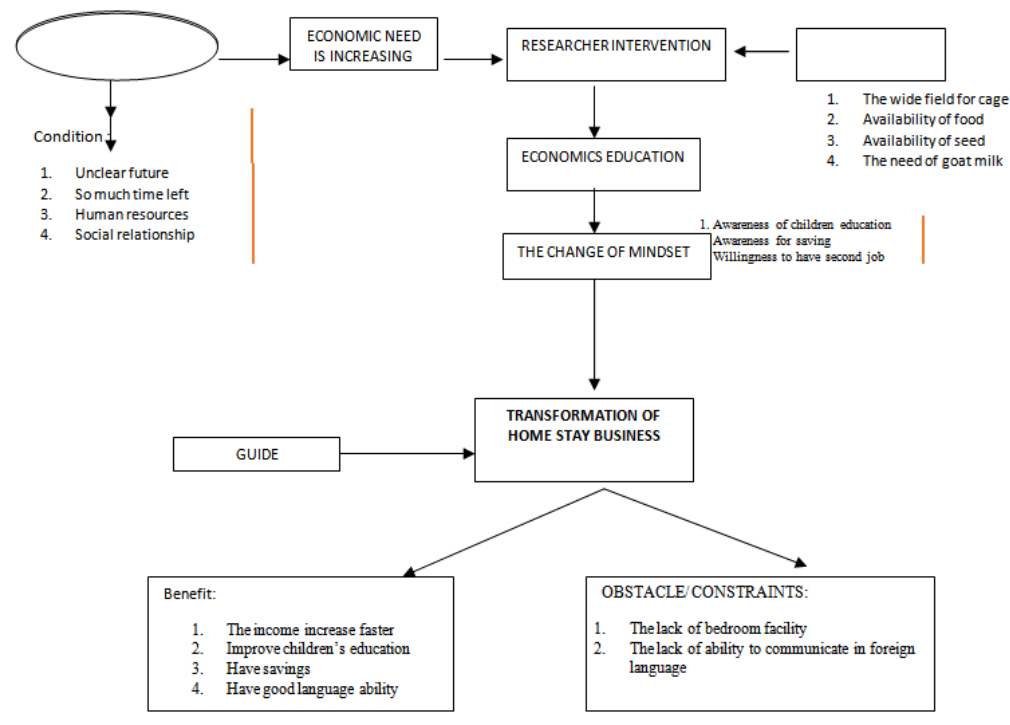

Figure2: Transformation process of sulfur miners to home stay business

\subsubsection{Making Pond Fish And Chicken Poultry}

There are sulfur miners who are over 45 years who have tried to make changes in the economy in the form of goats and fish ponds which also utilize the existing potential of their environment. Making a fish pond has also become the main attraction for foreign tourist staying in the sulfur miners' house, in addition to the water which flow is very cold and clear, fish ponds can be used by tourists who stay in the miners' house.

Results obtained from this business or side job is now starting to be used as savings by the sulfur miners. Beside they already can set aside their income as savings, the sulfur miners who already have a second job do not worry about things that are likely to occur either at the top of Mount Ijen and the physical abilities which began to decline.

One of the efforts carried out by researchers together with sulfur miners in an attempt to improvethe welfare is by making a fish pond based on a group of miners that have been formed. The fish pond is made in Dusun Glondok, LicinVillage, the early preparation is carried by 19 sulfurminers with an amount of as much as 2 pools, which are $3 \times 3 \mathrm{~m}$ and 2 large pools which are $3 \times 5 \mathrm{~m}$. The pool of sulfur miners kolan researchers have set up with a capacity of 15,000 seeds seed with a death rate of about 3000 seeds.

Catfish pond management requires extra attention, so that the miners made schedule to take turn in managing the pond, to feed the required 15 sacks at a price of 320,000 IDR per sack. At first glance, it is hard for sulfur miners, but when the first step has been running,the sulfur miners can run it by themselves in accordance with the science that they have studied together with the group.

For the results that can be obtained from the management of the fish pond for about 4 months, the miners could sense their relief that in fact there is another work to do in the environment where the living environment is very supportive. Yields of fish ponds, especially catfish pond that has been tested, yielded good results despite not yet be said to the maximum results. Yields of about 12,000 remaining seeds can produce 481 $\mathrm{kg}$ of catfish with a selling price of 15,000 IDR per kilogram. With that results, the sulfur miners in the Glondok Village have initiative to develop the results of science and catfish farming in their own homes.

\section{CONCLUSION}

\subsection{Conclusion}

Sulfur miners in Banyuwangi essentially has been a polemic that needs to be considered, especially in the economic field as well as health. Incomeof the sulfur miners only can meet their daily basic needs, so if they keep relying on the job as sulfur miners, they cannot fulfill other needs such as education and health. The children of sulfur miners cannot get education at a high level due to the cost limitation and also the lack of awareness of the importance of education.

Sulfur miners who are still young have started opening their insight into the meaning of education and saving for old age or future, it can be seen from the desire of miners to create a second job, such as becoming a tour guide, providing a home stay or make a fish pond around their houses. The results of the pond which are made by sulfur miners it can be used as an example for the other miners to follow the steps for other sulfur miners to follow the steps of making fish pondsas an effort to earn extra income for sulfur miners 


\subsection{Suggestion}

Sulfur miners who already have a second job as much as possible deliver their knowledge to theother miners to be able to follow the steps, so that later they can fulfillthe needs in their lives other than basic needs, such as education of their children.

The role of government of Banyuwangi is really necessary, it is because that until now sulfur miners isstill one of the attractions in the area of Mount Ijen. With the absence of sulfur miners who carry sulfur traditionally, the tourist attraction of Mount Ijen will be reduced. Therefore, the role of the government to maintain the sulfur miners in order to remain working as sulfur miners is really necessary.

\section{REFERENCES}

[1] Aliya, Economic transformation of minewoker of sulfur evaluated from education of economics in Ijen Mount Banyuwangi Indonesia, Proc. ICEEE 1st international conference on Economic Education and Entrepreneurship Learning Innovations, Surabaya, Indonesia,366-408 2016,

[2] Sudjana, Djuju,2004, Peranan Keluarga Dalam Lingkungan Masyarakat. Remaja Rosdakarya, Bandung

[4] Abdullah, Irwan, Tantangan pembangunan ekonomi dan transformasi sosial suatu pendekatan budaya. Jurnal humaniora Vol XIV No 3 Tahin 2002 Yogyakarta.

[5] sugiyono.2007. metode penelitian Kuantitatif, kualitatif dan R\&D. Bandung Alfabeta.

[6] Miles,M. B \& Huberman, A.M.1992. Analisis Data Kualitatif, Buku Sumber Tentang Metode-metode Baru, Jakarta, Universitas Indonesia

[7] Emzir.2008. Metodologi Penelitian Kualitatif analisis data. Jakarta Rajawali Pers

[8] Aliya, Economic transformation of minewoker of sulfur evaluated from education of economics in Ijen Mount Banyuwangi Indonesia, Proc. ICEEE 1st international conference on Economic Education and Entrepreneurship Learning Innovations, Surabaya, Indonesia, 366-408,2016,

[9] Rizanti, Idha. 2007. Profil kehidupan Penambang Belerang Di Sekitar Kawah ijen (Suatu Studi Di Desa Tamansari Kecamatan Licin Kabupaten Banyuwangi). Jember: Universitas Jember. 